\title{
On The Wire
}

\author{
spin offs \\ A production of the Console-ing Passions books series \\ Edited by Lynn Spigel
}




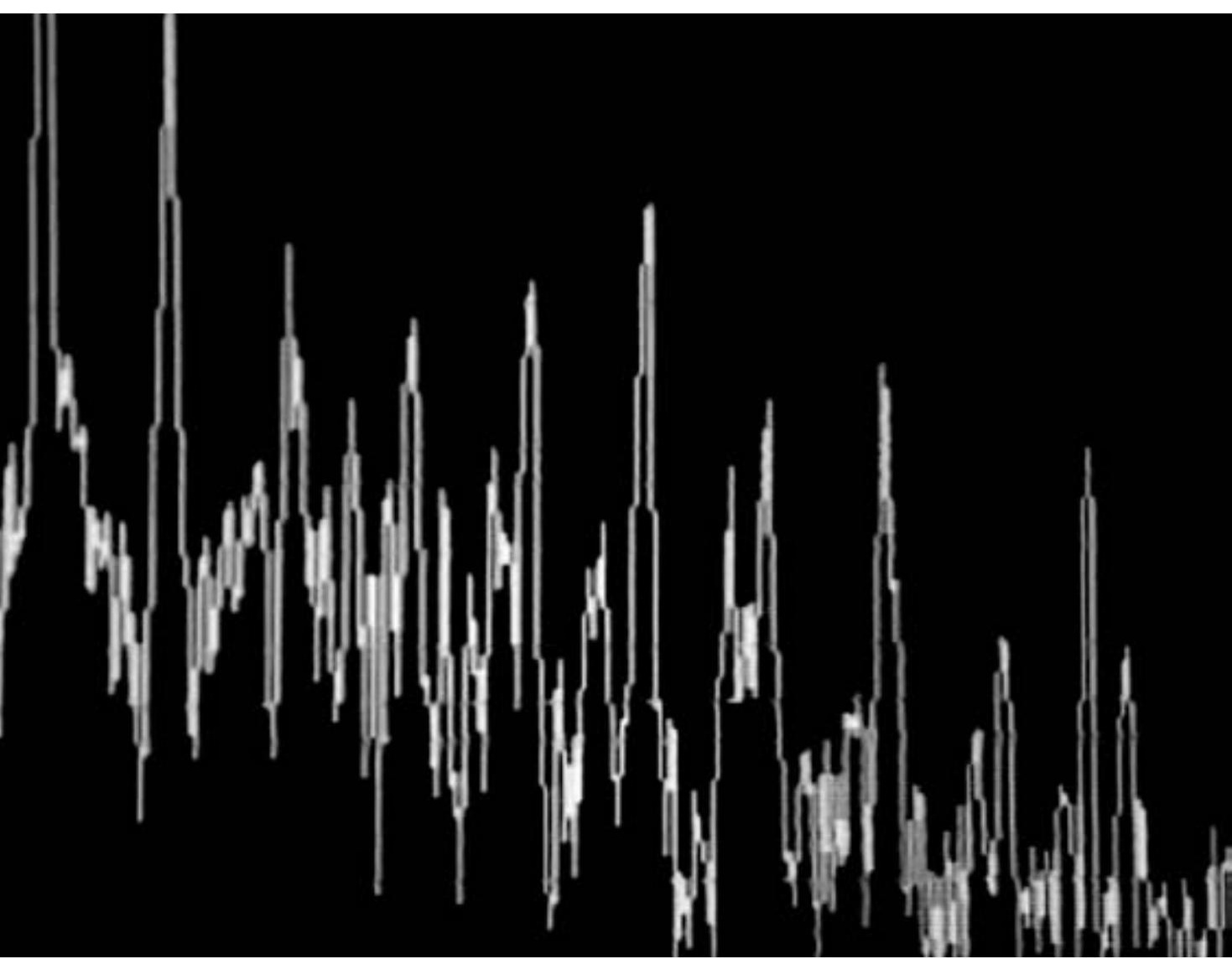




\section{On The Wire}

LINDA WILLIAMS

DUKE UNIVERSITY PRESS Durham and London 2014 


\begin{abstract}
(C) 2014 Duke University Press
All rights reserved

Printed in the United States

of America on acid-free paper @

Typeset in Warnock Pro by Tseng

Information Systems, Inc.
\end{abstract}

Cover art: Still from The Wire.

Courtesy of Photofest.

Library of Congress Cataloging-

in-Publication Data

Williams, Linda, 1946-

On the Wire / Linda Williams.

pages $\mathrm{cm}$

Includes bibliographical references and index.

ISBN 978-0-8223-5706-3 (cloth : alk. paper)

ISBN 978-0-8223-5717-9 (pbk. : alk. paper)

1. Wire (Television program). I. Title.

PN1992.77.W53 W52 2014

$791.45^{\prime} 72-d c 23$

2014000762 